\title{
Nietzsche e a sífilis: o polêmico diagnóstico do Dr. Möbius*
}

\author{
Christian Niemeyer**
}

Resumo: A intenção do artigo está em reabilitar o diagnóstico de sífilis de Nietzsche proposto pelo neurologista alemão Paul Möbius, autor da obra Nietzsche. Doença e filosofia (Nietzsche. Krankheit und Philosophie). Para tanto, ele traz a relação ambígua que o médico estabelece com a irmã do filósofo - sempre ávida em elucubrar versões para desviar da hipótese do acometimento por sífilis -, traz à luz o comentário de Möbius sobre o "acidente" que teria vitimado o pai de ambos, evidencia a correlação entre paralisia e sífilis, compara as versões de Elisabeth e do próprio Möbius para a anedota do bordel (1865), narrada por Paul Deussen, deslinda as excessivas (e sugestivas) preocupações do filósofo com o nariz, que poderia ser afetado como decorrência da sífilis. E, não por último, se Möbius erra ao excessivamente patologizar suas interpretações de Nietzsche, o texto faz ver o quanto a patologização de elementos do percurso intelectual do filósofo contribuiu para a transmissão despreocupada de sua obra.

Palavras-chave: diagnóstico, sífilis, paralisia, patologização, nariz.

\footnotetext{
* Tradução: Saulo Krieger.

** Universidade Técnica de Dresden, Dresden, Alemanha.

ORCID: http://orcid.org/0000-0001-5024-0123

Correio eletrônico: niem.ch2020@outlook.de
} 
Niemeyer, C.

"Faça exercícios de ginástica, mantenha o nariz

fechado durante horas com frequência"

(Jenaer Krankenjournal, 17 de junho de 1889)

Antes que eu, quando próximo do final desta explanação, possa elucidar a segunda parte da epígrafe e o motto do documento oculto, permitam-me iniciar com as premissas de um e de outro, isto é, com a crítica (atual) dirigida a Paul J. Möbius (1853-1907), mais precisamente ao seu livro intitulado Über das Pathologische bei Nietzsche [Sobre o patológico em Nietzsche] (1902). Trata-se de um clássico da literatura patográfica sobre Nietzsche, oriunda da verve do inventor do termo "patografia" ( $c f$. Dahlkvist 2012, p. 173). No entanto, já no momento de seu surgimento, a obra foi um acontecimento de primeira grandeza, assim como celebrado foi então seu autor, doutor em filosofia que era também médico e detentor de cátedra em neurologia e psiquiatria. Um exemplo atual: em sua espantosamente $^{1}$ bem-sucedida biografia sobre Elisabeth FörsterNietzsche, intitulada Die Schwester [A irmã] (2016), Kerstin Decker refere-se a Möbius como uma "infelicidade vagabundeante de um psicólogo", que "já antes chamara a atenção, com trabalhos pioneiros como Über den psychologischen Schwachsinn des Weibes [Sobre a deficiência mental na mulher] (Decker 2016, p. 417). Também seguidores de Kerstin Decker nesse segmento biográfico especial, como Ulrich Sieg, tecem juízos pouco elogiosos ao autor, ${ }^{2}$ o mesmo se aplicando (em ordem cronológica decrescente) a Reto Winteler (mediante desdém), ${ }^{3}$ Helmut Koopmann, ${ }^{4}$ Richard Schain (mediante

1 Para uma melhor elucidação desse termo, $c f$. Niemeyer 2018.

2 "É evidente que o panfleto não poderia ficar sem resposta" (Sieg 2019, p. 203).

3 “O que Overbeck poderia ser levado a pensar em função dos argumentos de tal 'especialista', isso é algo difícil de compreender" (Winteler 2014, p. 200).

4 Ele reprovou as "hipóteses vagas" (Koopmann, 2012, p. 160) de Möbius, mas, em compensação, elogiou as de Christiane Koszka (2010), como a da síndrome de MELAS, por ela introduzida (ibidem,

26 | Cad. Nietzsche, Guarulhos/Porto Seguro, v.41, n.1, p. 25-61, janeiro/abril, 2020. 
elogio ambíguo ${ }^{5}$, esses três últimos sendo ferrenhos opositores do diagnóstico de sífilis, o que sugere a seguinte pergunta: seria aqui o caso de fulminar o mensageiro em função de sua perturbadora mensagem? No presente artigo, nosso objetivo é investigar essa questão, levando em conta a mensagem de Möbius sobre o pai de Nietzsche (2); pretende-se discutir a leitura por Möbius da anedota do bordel, narrada por Paul Deussen, comparando-a à da irmã (3), assim como o caráter falho de Möbius como intérprete de Nietzsche (4). O artigo compreenderá um epílogo, do qual o "apontamento sobre o nariz" de junho de 1889, aqui trazido sob a forma de motto, faz-se fecunda comprovação do diagnóstico de sífilis por Möbius (5).

\section{A mensagem de Möbius a Nietzsche em comparação com a que enviou à irmã, Elisabeth}

Para poder responder à tal questão de modo convincente, consideremos uma vez essa mensagem de maneira mais atenta. A compreensão do motivo da peculiar indignação de Kerstin Decker ("desgraça vagabundeante") demanda que antes se esclareça que o "psicólogo" (Decker) e antifeminista Möbius não seria exatamente uma pessoa a exalar simpatia. Isso já se mostra na ocasião em que ele, irritado com uma oferta de uma vaga acadêmica aberta, mas na sua opinião de fato já oferecida a alguém, desistiu de apresentar a documentação para a sua habilitação. Além disso, no prefácio à segunda edição, de 1904, Möbius desacreditou um crítico próximo de Elisabeth (Raoul Richter), alegando que ele próprio, Möbius, infelizmente não poderia "se envolver em debate sobre o diagnóstico da paralisia com um professor de filosofia” (Möbius 1909, VI). O prefácio, já na primeira edição, foi lavrado nesse tom e continha uma

\footnotetext{
p. 158) - diagnóstico este que, ele próprio tendo sido há muito desmontado, não serve para muita coisa além de uma "vaga hipótese".

5 "Möbius is particularly informative about Nietzsche's migraine headaches [Möbius é particularmente bem informado acerca das dores de cabeça de Nietzsche]" (Schain 2001, p. 81).
} 
Niemeyer, C.

primeira ameaça: seria obrigatório "escrever algo sobre a doença de Nietzsche", e um parecer de especialista "não poderia se pautar por algo como uma reverência para com a família". E segue-se um ambíguo agradecimento à irmã do filósofo, que o tratara com "amistosa benevolência" por ocasião de uma visita, ao que ela "deu a sua autorização para as pesquisas que se fizessem necessárias", ao que acrescentou:

Inicialmente, a irmã nos disse que Nietzsche sofria de paralisia progressiva; como esta doença é exógena, a enfermidade surge de males externos, contra os quais a natureza do enfermo nada pode fazer (Möbius 1909, VI).

O comentário, que habilmente punha em jogo a distinção por Möbius entre exógeno e endógeno, deveria tranquilizar a irmã de Nietzsche, como também a tranquilizaria o relatório de suas observações, publicado em janeiro de 1900: Möbius as apresentou sem qualquer suspeita de que os relatos dela consistiam, na maioria, de invenções baseadas em falsificações - o que sem dúvida eram, algo que em breve será esclarecido, ainda mais que Decker, a advogada de Förster-Nietzsche, não diz uma palavra a respeito.

O ensaio de Förster-Nietzsche intitulado Die Krankheit Friedrich Nietzsches [A doença de Friedrich Nietzsche], publicado em 9 de janeiro de 1900 no Zukunft, jornal de Maximilian Harden, introduziu a hipótese de que "nosso pai teve uma doença no cérebro" (FörsterNietzsche 1900, p. 622), e isto vinha bem no sentido contrário ao de um debate sobre hereditariedade que então vigorava, desencadeado por Ola Hansson (1889/90) e conduzido por Hermann Türck (1891). O ponto mais intrigante dessa revelação estaria na explicação da irmã para o colapso de Nietzsche em Turim, em janeiro de 1889 (e o interesse por tal só fez aumentar após a morte do filósofo), explicação que tanto mais se fez necessária uma vez que o diagnóstico até então privilegiado, de "excesso de trabalho" já não mais se sustentava. Muitos dos que visitavam Nietzsche durante a década 
de 1890 voltavam para casa com variantes desse diagnóstico. 0 mais impressionante com relação a isso foi o relatório que o autointitulado "médico naturalista" Philo vom Walde emitiu em 1898:

A Sra. Pastor Nietzsche e sua filha são adeptas convictas dos métodos de cura higiênico-dietéticos (cura natural), e foi com uma dor profunda que vieram a perceber que seu amado Fritz se valera de todo o tipo de medicamentos para combater a insônia e as dores nevrálgicas. Esses medicamentos mostraram-se gradativamente nocivos a seus nervos cerebrais, até que Fritz veio a sucumbir pelo uso do cloral (cit. segundo Gilman 1981, p. 702).

A partir de 1900 essa explicação caiu em desuso, porque insuficiente. Elisabeth, no último volume da alentada biografia do irmão, Der einsame Nietzsche, escreveu em 1904 para repeti-lo quase que inalteradamente na edição de 1914:

Em alguns escritos anônimos, de modo realmente astucioso, buscaram instilar em meu irmão a crença de que meu marido tinha enviado, da América do Sul, três artigos contra o Zaratustra, e de que os teria publicado num jornal antissemita com a sua própria autorização e mesmo com a minha. $\mathrm{O}$ escrevente anônimo queria se vingar de meu irmão por algumas declarações que ele dera, amistosas a judeus e contrárias ao antissemitismo; e para mostrar ao mais solitário dentre os solitários que ele perdera até mesmo os poucos que estavam próximos de seu coração, escreveu a ele essas invenções maldosas. Meu irmão se sentiu ferido de morte. Em seu abandono, já não podia falar com mais ninguém. Só mesmo após a morte de meu marido [...] encontrei entre seus papéis a carta em resposta de Friedrich que me fora ocultada. Nessa carta ele fala desses ataques ultrajantes, e, com expressões de pesar, queixa-se a meu marido por ele ter alienado e corrompido a irmã caçula, que lhe era tão cara. A meu marido ele direcionou as mais amargas queixas e acrescentou: "Tomo soníferos e mais soníferos para aplacar a dor, e mesmo assim não consigo dormir. Hoje vou querer tomá-los em quantidade tamanha, que me faça perder a razão...” (Förster-Nietzsche 1900, p. 636).

- o que daí também se passou, pode-se depreender pelo que escreve a irmã, em variante nitidamente mais tranquilizada, de março de 1904: 
Niemeyer, C.

A carta como um todo soava como o último grito de seu coração atormentado, - um derrame cerebral acometeu o meu ente mais querido nos últimos dias de 1888, vindo paralisar para sempre este espírito incomparável (FörsterNietzsche 1904, p. 897).

Aqui, como também na edição de dez anos depois do Der einsame Nietzsche, o que prevalece é a causa do "derrame cerebral" (Förster-Nietzsche 1914, p. 524), que teria acometido Nietzsche pela primeira vez em dezembro de 1888 em Turim e pela última vez pouco antes de sua morte.

O que salta aos olhos nessa variante da historieta de 1900 é o local da publicação. Pois Maximilian Harden, fundador e editor da Zukunft e quase ferido de morte em 1922 por franco-atiradores de extrema direita (veio a sucumbir em 1927, em decorrência desse atentado), era originalmente de fé judaica, de modo que a irmã de Nietzsche de certa forma teria calculado que sua explicação para a morte do irmão só teria aprovação [do editor] se contivesse alguma frase de efeito antissemita. E que não se esqueça: a frase de efeito haveria de conduzir os futuros leitores do irmão, bem como seus futuros patrocinadores, para fora dos círculos judaicos. Nesse detalhe já é possível reconhecer o calculismo tão próprio de Elisabeth, a abranger todos os passos de sua argumentação - o que também não exclui algum desprezo pelos detalhes. Pois, com a sua insinuação de 1900, o escrevente anônimo, um antissemita, fizera referência "a alguns comentários amistosos a judeus e contrários ao antissemitismo da parte de meu irmão", e isso ela torna mais preciso em 1904: "Querendo se vingar dos últimos escritos de Nietzsche" (Förster-Nietzsche 1904; p. 896) e ao emitir sinais de culpa pelo colapso do irmão em Turim, em janeiro de 1889, tem-se aí atitudes que permitem ao leitor crítico comparar esses antissemitas com judeus, uma vez que ambos teriam seu modo de proceder conduzido por ressentimentos - para o antissemita essa comparação seria uma indignidade. E isso, segundo o cálculo de Elizabeth, era algo a se levar 
em conta em face da aparente conclusividade do argumento como um todo. Em 1904, ela refinou o raciocínio, a ponto de apresentar o oponente de Nietzsche como "inimigo da espécie dos insidiosos anões pequenos, que odeiam tudo o quanto é elevado e além-do-humano“" (ibidem) - uma variante não sem segundas intenções, que à sorrelfa afirmava o que no Ecce homo Nietzsche enunciava claramente: que a referência aos "anões insidiosos" (GT/NT 24, KSA 1.154) de $O$ nascimento da tragédia tinha conotações antissemitas, bem no espírito de Richard Wagner ( $c f$. Niemeyer 2011). De qualquer maneira, o preço a pagar por isso, uma vez que o Ecce homo ainda não tinha sido publicado, seria algo próximo de zero: sendo assim, Elisabeth poderia sugerir herdeiros espirituais de seu recém-falecido marido Bernhard Förster no movimento popular, com Nietzsche estando entre eles e aparecendo como figura odiada pelos judeus, ou seja, pelos tais anões insidiosos.

Por certo que ela não foi capaz de indicar um único original desse "escrevente anônimo" no espólio do irmão - e não chega a muito surpreender o inteiro processo ser fruto de sua fantasia, ou então se pergunte, de modo mais preciso: qual seria o efeito da energia criminosa de Elizabeth no ato de ocultar o diagnóstico de sífilis de Friedrich por todos os meios possíveis para favorecer o diagnóstico de derrame cerebral e da expressão, sempre de sua preferência, de "paralisia atípica" (Förster-Nietzsche 1900, p. 639)?

Teria sido essa uma variante da campanha aberta que viria a assumir quatro anos mais tarde, contra a "repugnante calúnia", que conferia ao irmão o diagnóstico da sífilis?

Os médicos chamaram a sua doença de uma 'forma atípica de paralisia', isto é, uma paralisia que de modo algum traz os sinais dessa doença $-e$ portanto não seria paralisia (Förster-Nietzsche 1904, p. 922).

É nítido o modo como a irmã se utiliza aqui de Otto Binswanger posteriormente à publicação de declaração dada ao periódico de Jena 
Niemeyer, C.

de que "o transcurso e a duração da enfermidade de Nietzsche não permitem atribuí-la à sífilis" (p. 535), e por trás de tal afirmação se oculta uma verdadeira querela de especialistas. Biswanger ainda partia da hipótese, equivocada, de que não $100 \%$ (este que é o valor correto), e sim "no máximo $70 \%$ dos casos de paralisia poderiam ser remetidos à sífilis" (ibidem, p. 535), e entre eles é evidente que o de Nietzsche estaria incluído ( $c f$. também Volz 1990, p. 298). Só mesmo em 1922, nove anos depois de o japonês Hideyo Noguchi (1876-1928) "ter podido provar que no cérebro de pacientes vitimados por paralisia eram regulamente encontradas espiroquetas" [o bacilo causador da sífilis descoberto por Schaudinn em 1905], e assim sendo "paralisia é sífilis" (Kolle 4 1966, p. 38), o próprio Binswanger viria a conceder: "o diagnóstico de paralisia progressiva não pode ser posto em dúvida e, de acordo com o estado atual da ciência, esse padecimento é um patologia sifilogênica do sistema nervoso (cit. segundo Vulpius, 1923, p. 723).

Mas o que se tem é não apenas o fato de que em seu artigo no Zukunft em 1900, e também mais tarde, Elisabeth não ter podido apresentar nenhum original que lhe servisse de comprovação, mas também o fato de as verdadeiras cartas ou os rascunhos de cartas do irmão terem se extraviado, em seu lugar aparecendo outras cartas, que ela própria inventava. Desse modo, perdeu-se a trilha que levaria ao rascunho de carta que Nietzsche teria enviado quando ela estava no Paraguai, "datada presumivelmente de fins de janeiro de 1888":

Na verdade eu não sinto entre nós uma relação de antagonismo, mas simplesmente um completo estranhamento (- afinal, uma relação de oposição seria algo simples e cortês - e eu amo o antagonismo) (8, p. 238).

Em substituição, em 1900 ela apresenta uma carta que Nietzsche lhe teria endereçado, carta que, datada de 10 de fevereiro de 1888, saíra diretamente de sua fantasia e continha as seguintes linhas: 
Uma tensão insuportável tem se apossado de mim, dia e noite, produzida pela tarefa que se me apresenta, e pelo desgosto absoluto ante todo o tipo de conduta que me seria de valia em sua execução: isto é o que mais pesa. O sentimento de estar sozinho, a ingratidão geral e mesmo o desdém para comigo (cit. segundo Förster-Nietzsche 1900, p. 631 s.).

O sentido do exercício (de escrita): faltam ainda onze meses para o colapso de Turim - tempo mais do que suficiente, pois, para se criar um cenário de sobrecarga, o que provavelmente seria a intenção de Elisabeth, ou seja: tornar o colapso claramente uma consequência do abuso de comprimidos (para dormir), sobretudo do "cloridrato para dormir" (cit. segundo Förster-Nietzsche 1900, p. 633). Quanto a esse risco, ela ainda complementa, ele [o irmão] teria sido mal informado pelo médico, que "repetidas vezes lhe garantira ser o remédio inofensivo" (cit. segundo Förster-Nietzsche 1900, p. 634).

Sendo assim, após esse intermezzo, retornemos ao Möbius segundo Kerstin Decker. Por meio de pesquisa na literatura secundária, ela tinha podido saber do relatório anterior, ou melhor, considerando que se propunha a lançar um livro a respeito, ela teria de saber do relatório anterior. Pode-se bem presumir então que a ela teria se mostrado conveniente fazer um juízo mais benevolente de Möbius um médico, que, iludido por uma apreciação de todo encobridora e ardilosa de Elizabeth, segundo a qual o irmão "nos últimos tempos "estivera às voltas com uma série de decisões voláteis e confusas" e, pouco antes do colapso de Turim "fora acometido de uma doença profunda" (Möbius 1909, p. 177): são ambas impressões que, como já se viu acima, residiam em cartas supostamente encontradas por Elisabeth e por ela disseminadas no Zukunft de Harden, jornal com uma tiragem de no mínimo 14 mil exemplares. E diga-se, ainda uma vez, por de tal maneira ter espalhado as suas mentiras, Elisabeth deve ter ficado realmente grata a esse homem. Sua compreensão da existência de uma causa exógena não demandava que se pensasse em Nietzsche como tendo sido antes uma pessoa saudável. Nesse mesmo 
Niemeyer, C.

sentido, havia lugar para a hipótese complementar, "de que Nietzsche muito provavelmente estivesse fora de um quadro normal, sofrendo de dores de cabeça e com as faculdades mentais em desarmonia" (Möbius ${ }^{3}$ 1909, p. 2). Em resumo, e pensando pela perspectiva da irmã: também essa espada de Dâmocles, empunhada pela primeira vez por Ola Hansson, oscilava sobre ele tal como antes, tanto mais que o enunciado de Elisabeth, ancorado em Möbius, e contra a posição de Hansson publicada no jornal Zukunft ("viemos de uma família saudável tanto do lado paterno quanto do materno"; FörsterNietzsche 1900, p 621), fazia-se ponto de partida para a suas próprias pesquisas, que versavam, por exemplo, sobre um homem conhecido que no outono de 1867 falara ao tutor de Nietzsche sobre os êxitos literários de Friedrich, no que o tutor respondeu, "essa precocidade é algo que não aprecio, pois conheço a família bem demais, razão pela qual temo que Nietzsche vá terminar seus dias num sanatório" (Möbius 1909, p. 11) - Isso foi dito sem que na verdade se entrasse no mérito, tanto que Elizabeth não mostrou receio, e muito pelo contrário: por essa divulgação se deveria culpabilizar mais a Möbius do que Nietzsche.

\section{O posicionamento de Möbius sobre pai de Nietzsche em comparação com a da irmã}

Algo diferente se teve com a disposição de Möbius quanto a transmitir a narrativa da irmã para a morte do pai, com os pontos principais esperados por Elizabeth: o médico não duvidava de que nesse caso "teria havido uma grave doença localizada no cérebro, e um caráter hereditário dessa doença seria algo improvável" (Möbius ${ }^{3} 1909$, p. 15). Nesse contexto, é de modo completamente acrítico, e ao longo de algumas páginas, que Möbius cita uma carta da irmã para ele, introduzindo o assunto com palavras dela própria: "andei refletindo avidamente e nesse ínterim também acabei por encontrar algumas anotações que fiz para mim mesma sobre relatos de minha 
mãe e de outros parentes" (ibidem, p. 13) - essas anotações, ela as publicaria ainda uma vez, em 1912, em seu livro intitulado Der einsame Nietzsche (O solitário Nietzsche), desta vez numa versão um pouco menos dramática. Em seus pontos decisivos a versão dizia o seguinte:

Em fins de agosto de 1848, sobreveio-nos uma grande infelicidade. À noite nosso pai acompanhava um amigo até a casa deste. Ao retornar à casa paroquial, nosso cãozinho veio em sua direção, meu pai não o viu, por causa de sua miopia. Tropeçou, vindo a arremessar-se para frente, contra os degraus de pedra do calçamento do pátio. Acabou por contrair um traumatismo craniano. (Förster Nietzsche 1912, p. 18)

Quase trinta anos depois, na biografia de Elizabeth por seu primo Adalbert Oehler, a história da escada é novamente contada, mas agora numa versão nitidamente reduzida, complementada com a indicação de que "Joseph, o filhinho caçula, ainda uma criança de berço, $[\ldots]$ faleceu logo depois do pai”.

Dito com mais precisão:

[El]e padeceu de um mal que à época era comum em crianças, espasmos graves por ocasião do surgimento dos dentes (Oehler 1940, p. 43).

Ah, pois sim? Digno de nota é esse "à época", considerando que, num guia da saúde, de autoria de um patologista de Leipzig, do qual Nietzsche detinha um exemplar adquirido provavelmente em junho de 1875 na Basileia, pode-se ler:

Que em consequência dos dentes algumas crianças morrem ou pelo menos ficam seriamente adoentadas, tal só pode ser afirmado por mulheres velhas ou por médicos sem nenhum conhecimento do organismo infantil e de suas enfermidades (Bock 1870, p. 766).

É também notável que referência como essa até hoje, 130 anos depois, não tenha se produzido nos Estados Unidos. Seja como for, 
Niemeyer, C.

de um médico propagandista antissífilis, Richard Schain, lemos que, a contar de 1940, não há registro de um único texto sobre o tema: "Joseph, died at 22 months of age after manifesting seizures and a terminal "stroke" [Joseph morreu aos 22 meses de idade, após ter manifestado espamos, que cumularam com um "apoplexia" terminal]. E então prossegue, sem interrupção:

Not much can be said about the relationship of his illness to the problems of the rest of the family but it is another piece of evidence that the Nietzsche family was indeed affected by a predisposition to neurological disorders. ["Não muito pode ser dito sobre a relação de sua doença com os problemas dos outros familiares, mas tem-se aí mais uma prova de que a família de Nietzsche foi de fato afetada por uma predisposição a desordens neurológicas"] (Schain 2001, p. 3)

A primeira parte do enunciado me parece incorreta, uma vez que bom tanto do que foi dito por Schain está relacionado à doença de Joseph Nietzsche e à de seu pai - o único problema é que Schain não sabe disso ou não quer saber. A esse respeito, também Pia Daniela Volz discorda do diagnóstico da mãe, da irmã e do primo ("espasmo dentário"), propondo como causa mortis uma "infecção febril" (Volz 1990, p. 36), algo que o diagnóstico de Schain não contradiz: segundo Volz, e ainda antes da publicação de Schain e em publicações que lhe eram ignoradas ( $c f$. Niemeyer 1998, p. 79 s.), a morte do irmãozinho fez-se objeto de debate sobre se Nietzsche lera essa morte como uma espécie de - para de novo se valer de um guia da saúde encontrado em posse de Nietzsche - "syphilis congenita" (cf. Kunze 1881: p. 426 s.), e nesse caso teria interpretado o mal do bebê como uma sífilis recebida do pai sifilítico.

Tudo isso tomado como desdobramento, em 1902 a irmã de Nietzsche teria realmente se mostrado grata a Möbius, não tivesse ele, por ocasião de uma explanação pormenorizada sobre a carta contando do acidente do pai, acrescentado que "para Nietzsche a doença do pai foi algo de significativo“ (Möbius 1909: 15) - a questão

36 | Cad. Nietzsche, Guarulhos/Porto Seguro, v.41, n.1, p. 25-61, janeiro/abril, 2020. 
do acidente sendo assim lenda de família como que sacralizada e imposta por todos os meios pela irmã de Nietzsche, à custa de mentiras e armações. Mas o que Möbius não sabia, ou melhor, à época, em 1902, não tinha como saber, porque a informação fora ocultada por Elisabeth: nos escritos de Nietzsche a história da escada era trazida como sintoma, e não como causa da doença do pai ( $c f$. Janz 1979, vol. I: 46). Em um esboço autobiográfico de 1858, conhecido da irmã e que veio a ser publicado de maneira fidedigna apenas em 1933, ele escreve: "Em setembro de 1848, subitamente meu amado pai caiu numa indisposição doentia" (Nietzsche, 1994, vol. 1, p. 4). Pois a versão apresentada por Elisabeth em 1924 traz a passagem reformulada, e da seguinte forma: "Em setembro de 1848, meu amado pai subitamente adoeceu em razão de um acidente" (Förster-Nietzsche 1924, p. 10). Trinta anos antes (1895), Elizabeth ofereceu uma variante do episódio do acidente, mas fê-lo apenas com a especificação "significativamente doente" (cit. segundo Hödl 1994, p. 297). Essas diferenças de interpretação revelam de modo exemplar a calamidade que são os experimentos do tipo "edições aproximadas": no pior dos casos aqui em questão tem-se traços constitutivos de projetos de ocupação para cientistas desempregados, ainda em estágio de formação de seu laboratório, podendo reconstruir laboriosamente suas fontes, para então iniciar um verdadeiro trabalho. ${ }^{6}$ Desse gênero é a referência trazida por Elisabeth, que é um manuscrito original deixado pelo irmão, manuscrito que foi queimado em partes importantes, com a supressão do prefixo até certo ponto indecifrável de "disposição" [gemüths-, em referência à disposição doentia do pai] dando lugar à lenda de que ali originalmente haveria lugar para as palavras "em razão de um acidente" ( $c f$. Hödl 1994, p. 297). Um Hitchcock por certo sentiria inveja de tamanha imaginação, tanto mais que a irmã chegou

6 Comentários dos tipos apresentados recentemente por Ultrich Sieg, de que Förster-Nietzsche teria, com suas falsificações, ainda assim fornecido novas fontes, são inteiramente inapropriados e, de certo ponto de vista, cínicos (cf. Niemeyer, 2019). 
Niemeyer, C.

a se empenhar na artesania de diálogos imaginários. Revelador é o caso de Resa von Schirnhofer ao relatar que, tendo reportado à irmã que Nietzsche, em 1884, por ocasião de uma enfermidade, confessara o medo de entrar em estado de demência, como sucedera ao pai, recebeu de Elisabeth inequívoca reprimenda, que ela reproduziu com as seguintes palavras:

Nisso ela deu um passo para trás, assustada, e enfaticamente me falou que eu deveria levar em conta que o irmão o afirmara sob o efeito de um grave acometimento (cit. segundo Lohberger 1969, p. 444).

Essa anedota possivelmente vem tornar ainda mais claro o significado atribuído pela irmã à história da escada - e o quão feliz ela deve ter ficado quando Möbius lhe deu crédito.

\section{O posicionamento de Möbius sobre a anedota do bordel de Paul Deussen em comparação com a da irmã}

E eis que chega o grande porém: em seu livro de 1902, Möbius mostrou-se disposto a investigar a anedota do bordel contada por Paul Deussen -, e isso por si só, eis a minha tese, explica a indignação de Elisabeth (mas de modo algum a de sua biógrafa!) contra Möbius, em razão da qual ela cogitou até mesmo processá-lo criminalmente (cf. Fiebig 2019). Afinal, a compreensão que ela tinha da paralisia ("paralisia atípica") exclui exatamente o aspecto do qual Möbius estava bem ciente: o de que a paralisia, uma "doença exógena", um "efeito vindo de fora, como uma toxina que adentra o corpo", tinha de ter um acontecimento a lhe anteceder. Möbius não afirmou ali propriamente que tal toxina seria de caráter sifilítico, ao menos não expressis verbis. Mas isso permite sugerir, na linha de uma lenda que caiu feito uma bomba "na cena Nietzsche" daquele fin de siécle-, e a lenda é a seguinte: a tinta do texto de Elizabeth sobre a doença 
do irmão (texto enviado para o jornal Zukunft, de Harden) mal havia secado quando em 15 de outubro de 1900, no Wiener Rundschau, aparece um ensaio de título espetaculoso "A verdade sobre Friedrich Nietzsche", lançando água no vinho que a irmã acabara de servir. O responsável por isso: Paul Deussen, um dos amigos mais antigos de Nietzsche, de quem, como professor de filosofia e fundador da Sociedade Schopenhauer (1911) não se podia negar a seriedade. Pois Deussen, sem intencioná-lo de modo manifesto, tornou a lançar na agenda, e de forma duradoura, o tema da sífilis - em detrimento do derrame cerebral -, ao tempo mesmo em que, sob a forma de livro, com o inofensivo título de Lembranças de Friedrich Nietzsche [Erinnerungen an Friedrich Nietzsche] (1901), de forma completamente inocente lançava a anedota que se tornaria lendária no romance Doktor Faustus, de Thomas Mann:

Em fevereiro de 1865, Nietzsche viajou sozinho a Colônia, e lá foi levado às atrações da cidade por um porteiro; ao fim e ao cabo, pediu a este que o levasse a um restaurante. Mas eis que o porteiro o levou a uma casa mal afamada. "Eu me vi", contou-me Nietzsche no dia seguinte, "subitamente cercado por meia dúzia de criaturas envoltas em véus e lantejoulas, e elas me olhavam cheias de expectativa. Fiquei ali por um instante, sem fala. Então, como que por instinto, fui até o piano, como se ele fosse o único ser provido de alma naquele ambiente, e desferi alguns acordes. Eles dissolveram minha rigidez, e eu pude fugir dali" (Deussen 1901, p. 24).

A partir desse relato não há nenhuma razão para se aventar alguma hipótese que comprometa Nietzsche, salvo pelo modo como Deussen se refere ao caráter inesperado e atípico dessa vivência: "De acordo com isso, e por tudo o quanto eu sei sobre Nietzsche, eu poderia acreditar que a ele se aplicariam as seguintes palavras [...]: mulierem nunquam attigit (ibidem), o que Richard Blunck traduz para o bom alemão: "Er rührte nie ein Weib an" - "Ele jamais tocou numa mulher". (Blunck 1953, p. 109) Blunck, que de sua biografia em vários volumes sobre Nietzsche pôde concluir apenas um, sobre a 
Niemeyer, C.

infância e juventude do filósofo, engrossaria o coro dos que duvidam da referida anedota ou que a tomam por uma falsa lembrança de Deussen. ${ }^{7} \mathrm{O}$ que ele assegura categoricamente é:

Quem [...], como nós, conhece Deussen bem, não há de concordar com isso. Mesmo passados 20 anos da publicação desse relato, Deussen desfrutava de uma memória quase infalível, num grau mesmo extraordinário, e seu caráter autoriza a completa exclusão da hipótese de ele ter inventado a história. (Blunck 1953, p. 109).

Também a irmã de Nietzsche conhecia Deussen bastante bem e precisamente por isso não ousou contestar o viés da crítica sugerida por Blunck. A solução do problema levaria ainda algum tempo, ou, dito de modo mais preciso, até o ano de 1912, porque as anedotas duram pelo seu condão de entreter, mas sobretudo porque Helmut Koopmann (2012), o opositor mais engajado da anedota do bordel e sua atualização por Thomas Mann, não a reconhece de modo algum.

Em 1912, por ocasião da nova versão de O jovem Nietzsche que visava a dar conta dos anos estudantis do irmão -, não houve ali uma única palavra sobre a história do bordel, e no entanto dessa história surgiu uma versão, por assim dizer, antecipada, datando de outubro de 1864, e a história teria sido então encoberta por lembranças de um parente distante de Deussen, de nome Ernst Schnabel (Förster-Nietzsche 1912, p. 142), a quem Nietzsche, sua mãe e a irmã em 27 de setembro de 1864 descrevem de modo sucinto como um "comerciante jovem, extremamente amável", e complementam com a observação: "é o mais conhecido e mais forte dentre os rivais de Deussen". O objeto de amor em litígio entre os rivais é a segunda

7 Essa anedota se criou na sequência de uma série de lembranças de amigos de Nietzsche de seu período como estudante, bem como de contemporâneos seus, tendo-se aí testemunhos que vão sobretudo na direção do atestado de bons antecedentes emitido por Deussen em favor de Nietzsche, testemunhos esses publicados em janeiro de 1910, de autoria de Curt Wachsmuth (1837-1905) e Wilhelm Heinrich Roscher (1845-1921) (cf. Vulpius 1923). Com relação a isso deve-se lembrar que no grêmio estudantil de que Nietzsche fazia parte era frequente o provérbio: " $\mathrm{O}$ caminho do pecado é o caminho secreto para Colônia” (Küster 1911, p. 36; cit. segundo Chronik 2000, p. 122).

40 | Cad. Nietzsche, Guarulhos/Porto Seguro, v.41, n.1, p. 25-61, janeiro/abril, 2020. 
das garotas citadas na carta a seguir, chamadas "Johanna e Marie [...], dóceis moças, ainda que não façam o meu tipo, um pouco por falta de gosto no vestir, e muito por estarem sob a guarda de uma senhora idosa e muito carola". Sobre tal objeto de amor, Nietzsche ainda acrescentou sarcasticamente - em carta endereçada também à sua mãe - que por Marie ele tinha se deixado enredar numa disputa em torno de questões religiosas, saiu-se muito bem, mas terminou "lamentando" por ele, por seus pontos de vista. A segunda e última referência a Schnabel na correspondência de Nietzsche se encontra no período que vai de final de abril a início de maio de 1868, em carta de Nietzsche igualmente endereçada a Deussen (1901, p. 45 s.), na qual ele relata a "agradável notícia do casamento de Ernst Schnabel" (com a citada Marie, ao que tudo indica) e termina com: "Se quiseres felicitá-lo também em meu nome, tu me farás uma grande alegria“" (2, p. 271) - não apenas uma frase vazia, como quer parecer; foi algo de mais necessário, não mera satisfação de um desejo passageiro, como revela a história completa, apresentada por Deussen em 1901. Segundo ele, Schnabel, seu primo e "amigo mais próximo", parece ter sido um autêntico bon vivant, que, em 1874, portanto apenas seis anos após casamento, morreu em Havana de "febre amarela", 8 pouco tempo depois de ter migrado para lá, na sequência da morte da esposa. Nas recordações de Deussen sobre Friedrich Nietzsche, a morte dessa "moça de boa alma", por Deussen chamada "Mariechen" ["Mariazinha"] (Deussen 1901, p. 16) - a partir do nome de batismo de Maria Stürmer -, foi muito ruidosamente chorada. Sobretudo Deussen, como já relatado por Nietzsche em carta de 1864, tentara vigorosamente conquistá-la, em vão, restando-lhe então assistir ao quanto ela fez Schnabel infeliz. Segundo Deussen:

8 Em trabalhos de referência, publicados à época, lê-se: "Nas regiões costeiras de países tropicais, sobretudo das Índias Ocidentais, observa-se a ocorrência de doenças endêmicas, que acometem sobretudo imigrantes; em poucos dias os pacientes passam a apresentar febre tifoide, hemorragias e icterícia. A mortalidade é de $40 \%$ a 50\%. Tratamentos não surtem resultado" (Meyer 1878, p. 721). 
Niemeyer, C.

Despreocupado como era, montou um negócio com outro sujeito em Barmen, casou com a sua e minha Mariechen e viveu alguns anos maravilhosos e em alegria. O negócio não deu certo e teve de ser dissolvido; a tristeza corroeu Mariechen, ela deu ao marido um filhinho e morreu.

Mas as coisas ficaram ainda piores: pouco depois da morte do pai, em Cuba veio a falecer também o filho que ele deixara com os avós, e assim "fechou-se a tumba dessa grande tragédia de amor" (Deussen 1901, p. 17). Portanto, uma love story, com Deussen no papel do amigo, mas sobretudo como um enlutado em razão da mulher, sendo no entanto mais do que isso: uma tragédia possivelmente causada pela sífilis? Nós não sabemos, apenas suspeitamos, que no tão pormenorizado relatório de 1912 Elisabeth teria ignorado completamente o relato pecaminoso - talvez para sugerir que a história do bordel, datada por Deussen em fevereiro de 1865, coadunava-se muito mais com a pessoa de Schnabel que com a de Nietzsche, sendo bem possível que ele, Deussen, tenha trocado os nomes. E foi assim que, segundo ele narra em 1901 - num relato que será referido por Elisabeth em 1912 -, numa viagem ao Reno, certa noite, na Gasse Königswinter, Schnabel entabulou com Nietzsche "uma conversa bastante descontraída sobre um pobre jovem renano em busca de acomodação para passar a noite", ao que "Nietzsche soprava em seu ouvido e coqueteava: “sein's Liebchen, sein's Liebchen",, 9 e eis que segue então, no relato de Deussen:

Como que ao modo de penitência por esse incidente isolado, aconteceu que no dia seguinte, na sala do piano do Berliner Hof, pedimos uma garrafa de vinho e purificamos a alma com o magnífico improvisar de Nietzsche (Deussen 1901, p. 18).

9 É muito possível que Nietzsche aí estivesse fazendo referência ao poema de August Heinrich Hoffmann von Fallersleben, convertido em Lied por Brahms em 1860, "Der Jäger und sein Liebchen" [O caçador e sua amada], pronunciando equivocadamente o "sein" como "sein's" (N.T.).

42 | Cad. Nietzsche, Guarulhos/Porto Seguro, v.41, n.1, p. 25-61, janeiro/abril, 2020. 
Que se ressalte ainda uma vez: a irmã de Nietzsche referiu-se com detalhes a esse parágrafo em $O$ jovem Nietzsche (cf. FörsterNietzsche 1912, p. 142 ss.), sem dizer uma palavra sobre as quatro páginas da anedota do bordel apresentada por Deussen em fevereiro de 1865. Por quê? Uma suposição: considerando que os únicos ingredientes dessa anedota, por exemplo, Nietzsche tocando piano, estavam presentes já na cena da Königswinter em outubro de 1864ali, no entanto, tendo como personagem central alguém tão altamente questionável como Schnabel - em sua versão de 1912 Elisabeth contava sugerir aos que conheciam a historieta de Deussen que a referência dizia respeito não a fevereiro de 1865 (Colônia), mas a outubro de 1864 (Königswinter) - portanto não tinha o irmão como personagem principal, e sim o bon vivant e suposto sifilítico Ernst Schnabel, que morreu em 1874 de uma doença tropical.

Ora, essa relação de anedotas pode soar estimulante à pesquisa Nietzsche, ${ }^{10}$ em sua referência ao ano 1912 e ao de 1902, a remontar a Möbius e com isso à pergunta sobre como se relacionou com a revelação de Deussen. De modo puro e simples: Möbius fez relativamente pouco caso, proporcionando à "memorável" anedota de Deussen o acréscimo de que "deve-se inofensivamente admitir que até 1865 Nietzsche evitou todo contato possível", mas não "que tenha se mantido sempre assim", pelo contrário: “Com bastante frequência o próprio Nietzsche fala de sua curiosidade perigosa, razão pela qual pode-se bem acreditar que tal curiosidade se deteria ante as circunstâncias mais interessantes. $O$ prazer ele foi capaz de sobrepujar, o peso na consciência, não". O enunciado imediatamente subsequente por certo que frustrou as expectativas:

100 nome de Ernst Schnabel encontra-se numa espécie de terra incognita na Nietzsche-Forschung. Salvo engano, apenas no romance nietzschiano Der Hammer des Herrn (1994), de Otto A. Böhmer, que se passa, como os outros trabalhos do gênero, nos anos que sucederam o colapso de Turim, Schnabel aparece - num flashback em que Nietzsche é remetido ao outono de 1864 ( $c f$. Böhmer, 1994, p. 44 s.), mas sem nenhuma indicação ao debate sobre a sífilis. $O$ debate veio a ser posto em tela apenas por Paul Deussen ou por Böhmer, também este emergindo como biógrafo de Nietzsche ( $c f$. Böhmer, 2004), ou ainda por Elisabeth, com sua variação da narrativa de Deussen, publicada em 1912. 
Niemeyer, C.

Ocorre que não somos instruídos por meras suposições. Informantes cujos nomes não devem ser mencionados revelam que já em Leipzig Nietzsche teria tido intercursos sexuais, e que, mais tarde, de tempos em tempos, teria tido relações com pessoas que se punham à disposição para satisfazer as necessidades masculinas (Möbius 1909, p. 50).

Provas disso não há. Entretanto, deve-se atentar: em nenhum momento do livro Möbius mencionou o termo "sífilis", nem mesmo onde ele "com segurança" pensava poder dizer "que em Nietzsche a causa da paralisia deu-se antes de 1870 " (ibidem, p. 67), ou, em termos mais concretos: no ano de 1866, daí se considerando "o período de incubação" (ibidem, p. 188). Aqui, ao menos de maneira implícita, têm-se reflexos da carta de Nietzsche a Carl von Gersdorff, de 4 de agosto de 1865. Möbius cita a carta de forma incidental, mas é de maneira correta que se refere a algumas de suas passagens centrais (cf. 2 p. 76):

Em Bonn (1865), Nietzsche padecia de um "forte reumatismo, a subir dos braços para o pescoço, dali para a mandíbula e para os dentes, e isso me provoca as diárias e lancinantes dores de cabeça" (Möbius ${ }^{3} 1909$, p. 67).

Ernst Benda (1925), colega de profissão de Möbius, tem o direito de primogenitura quanto a ter lido essa carta como indício para daí extrair as consequências da cena do bordel de 1865, relatada por Paul Deussen (ou por uma cena nela inspirada um pouco depois): sífilis. Azar de Möbius, sorte para a irmã... e quanto à biógrafa de 2016, não seria melhor calar? Em todo caso, chamou a atenção (tantas vezes falha) de Möbius também o interesse incidental de Nietzsche por "estrangeiros" - são citados Stendhal, Flaubert, Dostoiewski, Baudelaire -, e esse fato o médico tematiza supondo que Nietzsche "sabia muito bem do fundo de enfermidade que neles havia, e de seu caráter incurável" (Möbius 1909, p. 60). Mas o fato de três dos citados terem o nome associado especificamente à doença da sífilis não é levado em conta - possivelmente porque Möbius, como no caso 
da comparação, alhures, do caso de Nietzsche com as "histórias de vida de pessoas famosas vitimadas pela paralisia (R. Schumann, Lenau e outros)" (Möbius 1909, p. 60 p. 129), tem em mente o mesmo significado ao valer-se dos termos "paralisia" e "sífilis". Não obstante, no texto forjado por Möbius, em cujo transcurso ele exorta o leitor a refletir "se Nietzsche teria padecido de neurastenia, de melancolia ou de obsessão" (Möbius 1909, p. 60, p. 55), faltam ambos os termos ["paralisia" e "sífilis"]. Pouco claro é também o discurso do "veneno causador da paralisia" (Möbius 1909, p. 60, p. 87), que cumulou na hipótese de que Nietzsche teria tido uma enxaqueca hereditária, agravada pelos efeitos da toxina" (Möbius 1909, p. 60, p. 88).

Já no prefácio à primeira edição do livro de Möbius, de março de 1902, tem-se a exortação à que se leia atentamente a obra de Nietzsche, incluindo a literatura secundária ( $c f$. Möbius 1909, p. IX), para se ter respostas a perguntas como: "Se a paralisia progressiva estava a incidir já enquanto Nietzsche redigia seus escritos, em que momento ela se iniciou e em que medida influenciou seus enunciados?" (Möbius 1909, p. 3). Perguntas como essa por certo não estão entre aquelas de que o médico, especialmente à época, deveria se ocupar. E que Möbius tenha erigido seu ideal profissional sobretudo em torno da neurologia, para ela adquirindo o venia legendi, isso é revelado pelo prefácio à nova edição de seu livro de 1902. Nesse livro ele se volta contra Raoul Richter, em razão de sua descoberta, que o destinatário August Vetter resume da seguinte forma:

O primeiro ataque [da paralisia progressiva] se deu em 1881; outro mais forte sucedeu-se em 1882; com esse teve início uma ascensão da curva da doença até 1884; um declínio prolongou-se até 1887, e em 1888 um novo recrudescimento veio resultar, já em janeiro de 1889, no colapso definitivo. Consequentemente, a concepção do eterno retorno, assim como a redação do Zaratustra, sobretudo de sua quarta parte, ocorreram sob um estado de excitação já no âmbito da paralisia; Para além de bem e mal, 
Niemeyer, C.

Para a genealogia da moral e mesmo $O$ caso Wagner, para não falar de grande parte de seus escritos preparatórios, foram redigidos no período de remissão; o Crepúsculo dos ídolos, e os escritos de 1888 que vieram a compor $O$ anticristo e o Ecce homo, por fim, teriam de ser considerados como produtos acabados da paralisia (Vetter 1926, p. 39).

Soa um tanto veemente - e não se coaduna de fato com a crítica dirigida a Möbius ( $c f .$, por exemplo, Amende 1907, p. 194 s.), a observação segundo a qual este, sobretudo quanto ao Zaratustra, teria errado ao se arvorar em hermeneuta. Também da parte de outros críticos a Möbius, por exemplo, Reto Winteler, comentários como "juízos de arrepiar os cabelos" (Winteler 2014, p. 202) fazem-se merecidamente alvo de críticas, uma vez que há observações análogas (às de Möbius) vindas de estudos mais antigos sobre a recepção pedagógica do Zaratustra ( $c f$. por exemplo Niemeyer 2011, p. 180 s.)

\section{O completo fracasso de Möbius como intérprete de Nietzsche}

Em seguimento ao que acima se afirmou e com intenção de generalização, tem-se que: os aforismos e os cantos de Zaratustra, incompreensíveis a Möbius e, por essa razão, a seu ver, fundamentalmente incompreensíveis, foram lidos por ele como indícios da insanidade do autor, a leitura se dando sem um esforço sério de interpretação e à revelia da circunstância de que o texto deveria ser lido como obra de arte tanto quanto como obra filosófica, portanto devendo valer para ele também critérios estéticos, mas não aqueles com que Möbius pretende lidar de maneira exclusiva: os éticos. O que Möbius, em sua intenção de desvelar Nietzsche, com suas lentes e um cânone de valores prenhe de moral cristã, identificou sobretudo no Nietzsche tardio foi uma lassidão do gosto, que ele resume da seguinte forma: 
De certo modo é um consolo que o traço mais feio da imagem de Nietzsche, sua difamação delinquente das doutrinas e disposições cristãs, possa ter responsabilidade em seu acometimento cerebral (Möbius 1909, p. 125).

Com esse arrazoado faz-se clara uma coisa: somente a psiquiatrização de Nietzsche, a patologização de elementos de seu percurso intelectual, abriu caminho para a sua transmissão despreocupada de seus componentes de sua obra.

O fato de Möbius ter fracassado em dar uma interpretação como que integral da obra Nietzsche revela-se também por uma análise mais precisa dos enunciados pelos quais, segundo ele, "não se tem nenhum sentido a descobrir" (Möbius 1909, p. 119). Nietzsche escreveu o seguinte (e Möbius escarneceu do modo como o fez): "A muitos parece agora a pior das maldades o que tem apenas doze sapatos de largura e três meses de comprimento!" (Za/ZA, Da prudência humana, KSA 4.185). É verdade que isso soa como algo completamente desprovido de significação - mas apenas quando não se vai a suas fontes, aos aspectos com que ele estava familiarizado. Quando se o faz, está-se a afirmar que a expressão "doze sapatos de largura" faz referência a uma disposição jurídica vigente na Idade Média, sobre as dimensões exigidas para que uma cela fosse de todo confortável para o detento. Algo semelhante vale para a segunda expressão enigmática (três meses de comprimento"). Com isso devese ter em vista a jurisprudência da época, pela qual a pena deveria ser de mais de três meses para que se recorresse a um tribunal do júri (e não apenas a um júri popular) (cf. KSA 14.307). Com isso se deve bem reconhecer, como nós hoje, na condição de herdeiros dos progressos da pesquisa Nietzsche temos condições de fazer, que o veredicto de Möbius contém apenas um juízo apressado.

Mais grave já é o seu escárnio ao livro IV do Zaratustra, em especial no que diz respeito à "repulsiva descrição da festa do asno", assim como aos versos "completamente disparatados" (Möbius 1909, p. 125) de "Entre as filhas do deserto". Pois esses versos - e isto 
Niemeyer, C.

Möbius, pensando na anedota do bordel de Paul Deussen, poderia facilmente reconhecer - adquirem sentido completamente novo e de grande impacto quanto à questão da sífilis. $\mathrm{O}$ médico, porém, mantémse fixado em escárnio e zombaria, a observar, por exemplo, que o poema fazia mais "fomentar o deleite de estudantes embriagados". Indo além, critica as repulsivas "blasfêmias", as "ofensas estéreis", a escorregadia "salada de palavras", pondo, por fim, a questão que se lhe fez manifestamente decisiva:

Como poderia Nietzsche admitir essas lamentáveis divagações em seu livro, não se mantivesse ele, de maneira contínua e duradoura, no estado em que elas foram redigidas? (Möbius 1909, p. 126).

Uma última pergunta retórica, que intercepta a conclusão do leitor: uma vez que Nietzsche estaria em tal estado de maneira duradoura, ou em todo caso predominante, criou-se a impressão de que naquelas passagens tais estados estariam transcritos "como estados passageiros de estimulação da paralisia" (Möbius 1909, p. 126). No resultado de seu estudo, Möbius aplainou a hipótese do "derrame cerebral" de Elisabeth - trata-se de uma certa excitação como precursora do ataque de paralisia (Möbius 1909, p. 187). E também sustenta que a longa duração da doença. E ele também não considera que a longa duração da doença apresente um forte obstáculo à possibilidade de contabilizar uma paralisia progressiva, ou seja, sífilis.

Se para tanto se contar o período da incubação, ou, segundo outra concepção, os ataques de enxaqueca e o período de distúrbios apenas físicos, aí teremos 34 anos, de 1866 a 1890, ou então 30 anos, de 1870 a 1900.

- esses números não teriam nenhum poder elucidador quanto aos efeitos da "disposição física vigorosa de Nietzsche" (que sem dúvida lhe prolongaram a vida), à ausência de alcoolismo e a toda 
a cuidadosa atenção que recebeu." (Möbius 1909, p. 188 s.) Essa última observação foi inequivocamente (mais) um serviço prestado para a irmã.

O fato de ele retificar muita coisa não deixa dúvida: "A tentativa deplorável, realmente diletante do Dr. Möbius só fez gerar confusão" e baseia-se "em hipóteses não comprovadas e relatos que parecem advir de um verdadeiro lamaçal de inveja, maldade e incerteza" (Förster-Nietzsche 1904, p. 898). No último volume de sua extensa biografia sobre Nietzsche, todos movimentos e acenos fazem as vezes de um acesso tímido a esse tema, e isso até propriamente a execução desta que aparecerá como injuriante questão central:

Ora, o que pensar da 'conscienciosidade' do Sr. Dr. Möbius? O que pensar deste que, a partir de uma afirmação ou suposição inventada, ousa conspurcar a memória do mais nobre dos homens, vindo falar de uma infecção por sífilis em 1866, construindo daí sua hipótese - quando, porém, com o mínimo esforço ele poderia chegar à verdade de que isso não passa de uma repugnante calúnia (Förster-Nietzsche 1904, p. 922).

De modo puro e simples, e servindo-se da ironia na linha de Kerstin Decker: na passagem citada, Elisabeth revela-se digna de uma futura ganhadora do prêmio Nobel e como um ícone do feminismo. O mesmo vale para o filósofo e psiquiatra de Leipzig Paul J. Möbius, com o devido perdão pela repetição da citação: "a infelicidade vagabundeante de um psicólogo" (Decker 2016, p. 417). É de fato engraçado que, em sua apresentação à valorosa obra intitulada Nietzsche (1913), também o literato Richard M. Meyer (1860-1914) tenha observado, e de maneira áspera, com relação a Möbius:

Ora, como pode um homem com a pretensão de se fazer representante da pesquisa em seu estado puro vir a enunciar tal juízo com tão inaudita frivolidade e com tão pouca fundamentação: com a mesma frivolidade e com a mesma infalibilidade com que lança ao mundo as afirmações risíveis de seu panfleto misógino (Meyer 1913, p. 174). 
Niemeyer, C.

Contudo, na obra de Meyer, que foi impelido para fora dos Nietzsche-Archiv com argumentos antissemitas, cuja mulher era amiga íntima da irmã de Nietzsche e acabou vítima do holocausto ( $c f$. Fiebig 2012), talvez ainda se possa encontrar o que não se tem na abordagem de Decker: em que pesem fontes amplamente acessíveis, a autora não dedica uma linha sequer a censurar a crítica áspera e desmedida a Möbius por parte da irmã de Nietzsche, assim como o sem-número de cartas falsificadas, por meio das quais Elisabeth pôde interpretar o colapso psíquico do irmão como consequência de um derrame cerebral provocado pela carta de um antissemita, e isto para poder afastar a suspeita de sífilis. Desse modo, ao final apenas os procuradores da irmã, homens como Karl Schlechta, por certo, têm assento no banco dos réus.

Esse tipo de observação pode ser direcionada também ao biógrafo de Elisabeth, Ulrich Sieg: não é o caso de mencionar os excessos presentes na citação da crítica feita em 1904 pela irmã a “Otto (sic!) Möbius" (Sieg 2019, p. 202), bastando a indicação de Sieg, que pode ser lida em solidariedade a ela: ${ }^{11}$ é evidente que o panfleto [aquele de Möbius] não é irrefutável" (ibidem, p. 203). Também outros (leitores dessas linhas) evidenciam que Möbius foi acerbamente criticado por leitores como Richard M. Meyer, como da mesma forma o foi, após 1933, por veneradores nazistas de Nietzsche (por exemplo, Härtle 1937a, p. 292), e por fim também se teve a crítica de Elisabeth um pouco à la Meyer em razão de seu método e de sua estratégia de argumentação (por exemplo, $c f$. Horneffer 1906, p. 104.; Gramzow 1907, p. 36, 63; Jonkoff 1911, p. 20), mas também em razão da nosografia por ele posta em termos incontestáveis (sífilis),

\footnotetext{
11 Essa rubrica pertence ao argumento de Sieg, que desconhece o "juízo muito desfavorável sobre Elisabeth" que se faz a partir de de 1945, bem como o seu "uso displicente de afirmações que soavam esplêndidas em torno de 1900, quando muitas pessoas ansiavam por um 'reencantamento' de um mundo tornado cada vez mais racional" (Sieg 2019, p. 212) - e com isso também pelo reencantamento de Nietzsche. Note-se: Tudo se pode ser justificado - é preciso apenas saber como (sobre a crítica a Sieg, $c f$. Niemeyer 2019).
}

50 | Cad. Nietzsche, Guarulhos/Porto Seguro, v.41, n.1, p. 25-61, janeiro/abril, 2020. 
o que acabaria por contradizer de modo flagrante o que até então se sabia, segundo Otto Granzow de maneira ambígua, "sobre a relação de Nietzsche com o sexo feminino" (Granzow 1906, p. 538). Que Granzow, assim sendo, venere a imagem heroicizante de Nietzsche, propagada pela irmã - esta que, de resto, era por ele criticada com veemência, justamente pela tendência à heroicização -, só mesmo dessa forma se poderá evitar a discussão suscitada por Möbius sobre a doença mental que já se manifestava no período tardio da obra de Nietzsche.

Acrescente-se, a título de conclusão, que a crítica a Möbius por Elisabeth, ainda uma vez supostamente em nome da honra do irmão e na luta contra o amigo da Basileia (e ex-colega) Franz Overbeck, morto precocemente (1905), de maneira injusta o toma por culpado de, por ocasião de uma visita de Möbius à Basileia, ter posto o médico na trilha da sífilis e de ter estado por trás de um registro sugestivo nos laudos clínicos do hospital de Jena (o "duas vezes infectado", de 1866; citado segundo Volz 1990, p. 381). Com implacabilidade comparável, a irmã de Nietzsche investiu também judicialmente contra Möbius, contra outros partidários do diagnóstico da sífilis e contra leitores que davam crédito a Möbius - por exemplo, o médico e psicólogo Willy Hellpach, ainda esta vez no jornal Zukunft, de Harden (de 13 de agosto de 1904) (cf. Fiebig 2019, p. 83) - no que esteve amparada por assistentes voluntariosos, como Walter Jesinghaus, aluno de Theobald Ziegler, que em toda e qualquer circunstância - como nas manifestações de Adalbert Düringer, que acreditava em Möbius (cf. Jesinghaus 1907, p. 16) - mostravam-se prontos a reconhecer que "nós, apoiadores de Nietzsche, rechaçamos veementemente as afirmações do Sr. Möbius [...] como uma insultuosa injúria" (ibidem, p. 76). Para ataques num nível mais elevado, Elisabeth arrebanhava assistentes solícitos como Raoul Richter. Essa mobilização já constitui uma história à parte, que será escrita em breve. A título de resumo, observe-se algo que nos pareceu apropriado para o caso de Hermann 
Niemeyer, C.

Türck ( $c f$. Niemeyer 2019c): o que acima se salientou estende-se ao Nietzsche como crítico, ou seja, sugere a ideia de que na passagem a seguir, de Para além de bem e mal, ele tinha em mente Möbius, bem como sua detratora, Elisabeth:

O homem indignado [...] moralmente falando pode ser superior ao sátiro sorridente e autossatisfeito, mas em todos os demais sentidos ele será o caso mais habitual, mais irrelevante, menos instrutivo (JGB/BM 26, KSA 5.45).

Não se deve esquecer, e também aqui isso parece se adequar tanto a Möbius quanto a Elisabeth: "E ninguém mente tanto quanto o indignado" (ibidem). Da mesma forma: Em ambos esses casos, mas também no caso de Türck, abre-se um abismo que, esclarecedor da história das ideias, é próprio do irracional, e isso tanto no coração dos cristãos quanto no da burguesia. Quem despreza esse abismo ou, inversamente, quem o amplifica, na verdade está a falar sobre Nietzsche, fazendo-o, porém, de um plano da história das ideias que é bem outro, derivado de uma liga à época tida por nova e estranha, cujos traços característicos incidem muito mais profundamente do que os que fazem alguém ser homem, mulher, médico ou - para render homenagem a Kerstin Decker - psicólogo.

\section{Epílogo: O "apontamento sobre o nariz" de junho de 1889 - comprovação definitiva pró diagnóstico de sífilis de Möbius?}

Agora, se ao final deve-se ainda uma vez olhar para o começo, que se retome a segunda parte da epígrafe. O texto ali foi extraído da anamnese do hospital de Jena, "provavelmente roubada" segundo veio a afirmar a irmã do filósofo ainda em 1931 (Förster-Nietzsche 1931, p. 122), e citada pela primeira vez por Erich F. Podach em 1929, com sua última versão tendo ainda uma vez sido reexaminada 
e publicada pela primeira vez por Pia Daniela Volz. ${ }^{12}$ Segue aqui a citação apresentada no motto e datada de 17 de junho de 1889:

"Faça exercícios de ginástica, mantenha o nariz fechado durante horas, com frequência" (cit. segundo Volz 1990, p. 401).

Não é algo de per si evidente que a equipe do periódico de Jena atribua significado especial a essa anotação - seja a seu título, seja ao que consta no "apontamento sobre o nariz". Também na própria pesquisa Nietzsche, segundo estou fazendo ver, até hoje ninguém no mundo levou em conta essa anotação, nem mesmo os que são da área, como é o caso de Pia Daniela Volz. Em sua dissertação Nietzsche im Labyrinth seines Krankes (Nietzsche no labirinto de sua doença), hoje considerada um trabalho de referência em medicina, Volz analisou uma série de artigos do periódico de Jena, assim como documentos semelhantes (ibidem, 254), mas sem tocar na questão do comentário sobre o nariz. Isso vale também - para trazer aqui mais um exemplo - para Christopher M. Owen, Carlo Schaller e Devin K. Binder, que também poderiam, via Erich F. Podach, acusar a equipe do periódico de Jena de uma espécie de decisão preliminar em favor do diagnóstico da sífilis ("the Jena records were made by persons who had paralysis (i.e., syphilis) in mind all the time" [os registros de Jena foram feitos por pessoas que tinham paralisia (i.e., sífilis) na mente o tempo inteiro] e, de modo complementar, concederam "powerful arguments" a Leonard Sax (2003) e Richard Schain (2001), "that Nietzsche did not have syphilis at all" [que Nietzsche não tinha sífilis], acrescentando, ademais, de modo confiante e bem no sentido do acima referido, "the actual event of Nietzsche's presumed infection is known only through third-hand accounts at best" [o evento real da suposta infecção de Nietzsche é conhecido, na melhor das hipóteses,

12 Foi também Volz que se referiu sutilmente ao relato sobre um desaparecimento e reaparecimento desse documento ( $c f$. Volz 1990, p. 390). 
Niemeyer, C.

apenas por abordagens de terceira mão] (Owen/Schaller/Binder 2007, p. 628) Perguntando, assim ainda uma vez, um apontamento tal qual o citado a partir do Jenaer Krankenjournal seria uma "third-hand information" [informação de terceira mão]? Ou não advirá da própria parte interessada, por isso devendo ser levada a sério e interpretada com cautela?

A pergunta é retórica. Segundo a minha proposta de interpretação, proferida sob a forma de uma tese: em 17 de junho de 1889, dia em que foi emitido o "apontamento sobre o nariz", "a arte do esquecimento" (NF/FP 40[46] do verão de 1888, KSA 13.557), que Nietzsche deplorara já no verão de 1880 (a esse respeito, $c f$. Niemeyer 2019), já não mais vigorava. Consequência: em face do que foi atestado sobre o paciente Nietzsche três meses mais tarde, "aqui e ali irrompe uma conscientização sobre a doença" (cit. segundo Volz 1999, p. 404) ${ }^{13}$ que até agora se mantivera artificialmente reprimida, a ansiar pelo direito de exercer influência no reino das coisas manifestas, por exemplo, sob a forma da desconcertantemente tranquila pergunta de Nietzsche, que podemos aqui empregar como subtexto ao registro de 17 de junho de 1889:

Oh, Deus, aconteceu o que eu de há muito receava: irrompeu a paralisia como o pior dos efeitos de minha infecção por sífilis, agora tenho de procurar o máximo possível dar um freio em suas outras decorrências fatais!

Essa longa tradução do que no discurso se mostra como breve epígrafe pode soar bastante forçada - mas isso somente quando se ignora o que uma obra de referência bastante utilizada à época de Nietzsche dizia no verbete "nariz": sob a rubrica "doenças do nariz" constava, em último lugar, em seguida a "constipação", "sangramento nasal" e "pólipos":

13 Semelhante a um registro de 30 de março de 1889: "Agora ele parece ter mais consciência de estar doente, sabe que está num hospital em Jena, chama tanto Binswanger quanto Ziehen pelo nome correto" (cit. segundo Volz 1990, p. 397).

54 | Cad. Nietzsche, Guarulhos/Porto Seguro, v.41, n.1, p. 25-61, janeiro/abril, 2020. 
Sífilis. Com frequência acaba por provocar destruição da porção mais externa das narinas (Meyer, 1878, p. 1330).

Nesse contexto, não chega a ser importante se Nietzsche leu esse verbete numa fase em que estava mentalmente são ou se soube a seu respeito de outro modo. $\mathrm{O}$ que realmente importa é, por exemplo, o que consta no verbete "sífilis nasal" ( $c f$. Kunze 7 1881, p. 419) o compêndio de medicina de C. F. Kunze, médico de Halle, cujo compêndio estava presente na biblioteca do filósofo (em sua sétima edição, 1881, 647 p.). A esse respeito, deve-se atentar ao conhecimento dos relatos de viagem de Gustave Flaubert (1850) ao norte da África, onde se encontraram sifilíticos com "buracos no lugar do nariz" (Flaubert 1977, p. 156). Nietzsche certamente detinha esse conhecimento, adquirido pelas Lettres à George Sand (1884), que ele comprovadamente estudou ( $c f$. Campioni et al. 2003, p. 227 s.). Contudo, e isto ainda uma vez poderia esclarecer um pouco mais o desinteresse da equipe do periódico de Jena: as preocupações de Nietzsche com o nariz foram injustificadamente ignoradas - a angústia tinha origem em descrições como a seguinte, de Alain Corbin, referida pelo historiador da medicina Jacques Léonard: “As horríveis ulcerações com que se deparou no norte da África desde a conquista da Argélia fortaleceram as convicções dos médicos de que a gravidade da doença na Europa fora amplamente negligenciada" (cit. segundo Corbin 1981, p. 128).

Mas como sempre: a edição de 17 de junho de 1889 do Jenaer Krankenjournal permitiu a afirmação de que Nietzsche, fazendo as vezes de bom hipocondríaco, dando-se continuamente em experimento (por exemplo, em Veneza, em 1885; $c f$. Volz 1990, p. 359 s.), ele próprio emitindo suas receitas, tinha ciência de seu acometimento por sífilis. E nessa mesma direção, como revelou seu colapso de janeiro de 1889 em Turim, pressentia estar adentrando o terceiro estágio, que seria o estágio final de sua doença venérea o da paralisia. Entre os indícios encontra-se a demência, gradual, 
Niemeyer, C.

inapelavelmente progressiva e por fim completa - estágio cujo início pode (e não tem de) ser percebido na "destruição da porção externa das narinas", referida no léxico de 1878. E a fim de deter esse quadro evolutivo, um meio adequado pareceu ao paciente Nietzsche manter esse órgão "fechado durante horas". Comovente (se é que se pode dizer assim) foi o fato de ele, para não deixar a equipe concluir que estaria com medo, ter ocultado o contexto dessa prática como parte de "exercícios de ginástica" (e essa ocultação, como comprovam o apontamento, o fato de a equipe do hospital não lhe ter dado importância, bem como os rumos que a pesquisa Nietzsche assumiu, foi bem-sucedida).

\section{Resultado final}

O que se segue desse exemplo de Möbius? Pelo que proponho, seria bem o caso de lhe fazer justiça, observando que o tom por ele assumido não deve servir de modelo para as objeções que se lhe vai fazer. E, o mais importante: o que se segue do "apontamento sobre o nariz" quando, na linha de interpretação aqui proposta, se toma a parte pelo todo? Segue-se, e este é o segundo ponto que proponho, que se deve fazer justiça aos que de modo algum aceitaram o diagnóstico de sífilis, empenhando novos esforços para poder fazer frente à sua interpretação. Que Möbius não tenha proporcionado um bom exemplo disso, tal foi apresentado no texto que precede, razão pela qual posso dirigir a ele o protesto que ele próprio lançou contra Raoul Richter: pesquisador de Nietzsche desde 1992, pesquisador da educação e psicólogo, eu não estou preparado para trazer citações de obras de Nietzsche em complemento a explicações oriundas estritamente do campo da medicina (de não especialistas em Nietzsche) para o diagnóstico da paralisia. Ou, dizendo-o de maneira mais contida e com o título de um artigo recentemente publicado sobre o tema ( $c f$. Niemeyer 2019b): um "diagnóstico de exclusão da sífilis" à la Richard Schain e Reto 
Winteler não seria nem honesto, nem possível, nem vantajoso -, ele seria, como eu agora, à luz do "apontamento sobre o nariz", eu acrescentaria, absurdo, pois contrário à empiria.

\title{
Nietzsche and Syphilis: Dr. Möbius Polemical Diagnosis
}

\begin{abstract}
The main purpose of the article is to rehabilitate the syphilis diagnosis proposed by the German neurologist Paul Möbius in his work Nietzsche. Illness and philosophie (Nietzsche. Krankheit und Philosophie). For this purpose, it reviews the ambiguous relation the physician maintains with the philosopher's sister always eager to elaborate versions to deviate from the hypothesis of a syphilis diagnosis -, brings to light Möbius' comment about the "accident" that would have befallen their father, evinces the correlation between paralysis and syphilis, compares Elisabeth and Möbius' versions to the brothel anedocte (1865), narrated by Paul Deussen, and eventually unravels the philosopher's excessive (and suggestive) concerns about his nose, that could be affected as an outcome of syphilis. And if Möbius makes a mistake in excessively pathologizing his interpretations of Nietzsche, the text also points to how much the patologization of elements of the intellectual pathway has contributed to the unconcerned transmission of his work.
\end{abstract}

Keywords: diagnosys, syphilis, paralysis, pathologization, nose.

\section{Referências}

AMENDE, D. "Fr. Nietzsches geistige Erkrankung und ihre Beurteilung durch P. J. Möbius”. In: Burschenschaftliche Blätter 21, 1907, n. 8, p.192-195.

BENDA, E. "Nietzsche's Krankheit". In: Monatsschrift f. Psychiatrie und Neurologie 60, 1925, p. 65-80.

BERNOULLI, C. A. Franz Overbeck und Friedrich Nietzsche. Eine Freundschaft. 2 vol. Jena: Diedrichs, 1908 
Niemeyer, C.

BOCK, C. E. Das Buch vom gesunden und kranken Menschen. Leipzig: E. Heils, 1870.

BÖHMER, O. A. Der Hammer des Herrn. Roman. Frankfurt a. M: Eichborn, 1994.

BÖHMER, O. A. Warum ich ein Schicksal bin. Das Leben des Friedrich Nietzsche. Leipzig: Reclam, 2004.

CHRONIK. Friedrich Nietzsche. Chronik in Bildern und Texten. München: Carl Hanser, 2000.

CORBIN, A. "Die erbliche Syphilis oder die unmögliche Erlösung. Ein Beitrag zur Geschichte der Erbkrankheiten". In: CORBIN, A Wunde Sinne. Über die Begierde, den Schrecken und die Ordnung der Zeit im 19. Jahrhundert. Stuttgart: Klett-Cotta, 1993.

DAHLQVIST, T. “Genie, Entartung, Wahnsinn. Anmerkungen zu Nietzsche als Pathograph und Objekt der Pathographie". In: Reschke, R. / Brusotti, M. (org.). Einige werden posthum geboren. Berlin/Boston: Walter de Gruyter, 2012.

DECKER, K. Die Schwester. Das Leben der Elisabeth Förster-Nietzsche. Berlin: Piper, 2016.

DEUSSEN, P. Erinnerungen an Friedrich Nietzsche. Leipzig: Brockhaus, 1901.

FIEBIG, N. Der Kampf um Nietzsche. Menschliches, Allzumenschliches von Elisabeth Förster-Nietzsche. Weimar: Weimarer Verlagsgesellschaft, 2018.

FÖRSTER-NIETZSCHE, E. "Die Krankheit Friedrich Nietzsches." In: Zukunft $30,1900$.

FÖRSTER-NIETZSCHE, E. Das Leben Friedrich Nietzsches. Zweiter Band. Zweite Abtheilung. Leipzig: Naumann, 1904.

FÖRSTER-NIETZSCHE, E. Der junge Nietzsche. Leipzig: Kröner, 1912.

FÖRSTER-NIETZSCHE, E. Der einsame Nietzsche. Leipzig: Kröner, 1914.

FÖRSTER-NIETZSCHE, E. (org.) Der werdende Nietzsche. Autobiographische Aufzeichungen. München, 1924.

GILMAN, S. L. (org). Begegnungen mit Nietzsche. Bonn: Bouvier, 1981.

58 | Cad. Nietzsche, Guarulhos/Porto Seguro, v.41, n.1, p. 25-61, janeiro/abril, 2020. 
GRAMZOW, O. Geschichte der Philosophie seit Kant. Erster Band: Von Kant bis Nietzsche. Charlottenburg: Georg Bürkner, 1906.

GRAMZOW, O. Kurzer Kommentar zum Zarathustra. Charlottenburg: Georg Bürkner, 1907.

HÄRTLE, H. Friedrich Nietzsche. "Der unerbittliche Werter des neunzehnten Jahrhunderts". In: Der Schulungsbrief IV, 1937, p. 290-299.

HANSSON, O. Friedrich Nietzsche. Seine Persönlichkeit und sein System. Leipzig: Fritzsch, 1890.

HÖDL, H. G. "Dichtung oder Wahrheit? Einige vorbereitende Anmerkungen zu Nietzsches erster Autobiographie und ihrer Analyse von H. J. Schmidt". In: Nietzsche-Studien 23, 1994, p. 285-306.

HORNEFFER, A. Nietzsche als Moralist und als Schriftsteller. Jena: E. Diederichs, 1906.

JESINGHAUS, W. Nietzsches Stellung zu Weib, Liebe und Ehe. Leipzig: W.Braumüller, 1907.

JONKOFF, Th. Nietzsches Idee vom Übermenschen als Erziehungsideal. Zürich, Dissertation,1911.

KLOPSTOCK, Th. "Friedrich Nietzsche und seine Krankheiten: kein ausreichender Anhalt für MELAS”. In: Nietzsche-Studien 42, 2013, p. 293-297.

KOLLE, K. Einfiihrung in die Psychiatrie. Stuttgart: Thieme, 1966.

KOOPMANN, H. Syphilis. "Wie ein Wort Nietzsche zu einer Krankheit verhalf, an der er nicht litt, und Thomas Mann zu einem Romanstoff, den es sonst kaum gegeben hätte”. In: MAIO, G. (org.). Macht und Ohnmacht des Wortes. Göttingen: Wallstein, 2012.

KOSZKA, C. "MELAS (Mitochondriale Enzephalomyopathie, Laktazidose und Schlaganfall-ähnliche Episoden) - eine neue Diagnose von Nietzsches Krankheit". In: Nietzsche-Studien 39, 2010, p. 573-577.

KUNZE, C. F. Compendium der Praktischen Medicin. Stuttgart: Ferdinand Enke, 1881. 
Niemeyer, C.

LOHBERGER, H. "Friedrich Nietzsche und Resa v. Schirnhofer". In: $Z$. $f$. philosophische Forschung 22, 1969, p. 248-260 e p. 441-458.

MEYER, R. M. Nietzsche. München: C.H. Beck'sche,1913.

MÖBIUS, P. J. Nietzsche. Ausgewählte Werke, vol. V. Leipzig: Johann Ambros Barth, 1909.

NIEMEYER, Ch. Nietzsches andere Vernunft. Psychologische Aspekte in Biographie und Werk. Darmstadt: Wissenschaftliche Buchgesellschaft, 1998.

NIEMEYER, Ch. "Nietzsche - nur Narr? Die Sprache des Zarathustra - und die Pädagogik. Eine Zwischenbilanz nach 125 Jahren Rezeptionsgeschichte". In: Zeitschrift für Pädagogik 57, 2011, p. 55-69.

NIEMEYER, Ch. "Winning ugly by untold stories? Kerstin Deckers ElisabethFörster-Nietzsche-Biographie, gelesen als typisches Produkt kulturindustrieller Gegenaufklärung". In: Aufklärung und Kritik 25, H. 1, 2018, p. 242-255.

NIEMEYER, Ch. Auf die Schiffe, ihr Philosophen! Friedrich Nietzsche und die Abgründe des Denkens. Freiburg i. Br.: Karl Alber, 2019.

NIEMEYER, Ch. Nr. 5 - Lakmustest nicht bestanden! Rez. zu Ulrich Sieg, Die Macht des Willens, 2019a. Elisabeth Förster-Nietzsche. München. In: Aufklärung \& Kritik 26, H. 4, 2019, p . 260-267.

NIEMEYER, Ch. "Nietzsche, Hoffnung, Syphilis. Teil I: Warum eine ,Ausschlussdiagnose Syphilis' à la Richard Schain und Reto Winteler weder möglich ist noch redlich und zielführend wäre”. In: BECHER, D. (org.): Brisantes Denken - Friedrich Nietzsche in Philosophie und Popkultur. Leipzig: Dominik Becher, 2019, 127-159.

NIEMEYER, Ch. Das Unglück, das nicht alleine kam: Hermann Türck und sein Versuch von 1891, Nietzsche als bête humaine von Émile-Zola-Format zu konfigurieren. Unv. Ms., 2019.

NIETZSCHE, F. Sämtliche Werke. Kritische Studienausgabe in 15 Einzelbänden. Hrsg. v. G. Colli u. M. Montinari. München: dtv, 1988.

NIETZSCHE, F. Sämtliche Briefe. Kritische Studienausgabe in 8 Einzelbänden. Hrsg. v. G. Colli u. M. Montinari. München: dtv, 2003. 
NIETZSCHE, F. Jugendschriften 1854-1861. J. Mette (org.). München: dtv, 1994.

OEHLER, A. Nietzsches Mutter. München: Beck, 1940.

OWEN, Chr. M. / Schaller, C. / Binder, D. K. The Madness od Dionysus: A Neurosurgical Perspective of Friedrich Nietzsche. In: neurosrurgery-online 61, n. 3, September 2007, 626-632.

PODACH, E. F. (org.) Der kranke Nietzsche. Briefe seiner Mutter an Franz Overbeck. Wien: Bermann Fischer, 1937.

RICHTER, R. Nietzsche. Sein Leben und sein Werk. 2a, ed.. Leipzig: Durr'schen Buchhandlung, 1909 (1903).

SAX, L. "What was the cause of Nietzsche's dementia?". In: J Med Biogr. 11, 2003, p. 47-54.

SCHAIN, R. The Legend of Nietzsche's Syphilis. Westport, London: Greenwood Press, 2001.

SCHIFFTER, R. "Friedrich Nietzsches Krankheiten - eine unendliche Geschichte". In: Nietzsche-Studien 42, 2013, p. 283-292.

SIEG, U. Die Macht des Willens. Elisabeth Förster-Nietzsche. München: Carl Hanser Verlag, 2019.

TÜRCK, H. Fr. Nietzsche und seine philosophischen Irrwege. Leipzig: Naumann, 1891.

VETTER, A. Nietzsche. München: E. Reinhardt, 1926.

VOLZ, D. P. Nietzsche im Labyrinth seiner Krankheit. Eine medizinisch-biographische Untersuchung. Würzburg: Königshausen \& Neumann, 1990.

VULPIUS, G. "Nietzsches Krankheit”. In: GILMAN, S. L. (org). Begegnungen mit Nietzsche. Bonn, 1981.

WINTELER, R. Friedrich Nietzsche, der erste tragische Philosoph. Eine Entdeckung. Basel: Schwabe, 2014.

Enviado: 05/08/2019

Aceito: 26/11/2019 